\title{
MALIGNANT TRANSFORMATION OF PLEOMORPHIC XANTHOASTROCYTOMA
}

\section{Case report}

\author{
Oswaldo Ignácio de Tella Jr', Marco Antonio Herculano², \\ Mirto Nelso Prandini ${ }^{3}$, João Norberto Stavale ${ }^{4}$, Paulo Henrique Aguiar ${ }^{5}$
}

\begin{abstract}
We report a case of a pleomorphic xantoastrocytoma which manifested itself as a cystic isodense lesion in the right fronto-temporal lobe in a 26 year-old woman. It appeared as a soft yellow tumor with cystic cavities on surgery. Five months after this surgery, the patient was submitted to a new operation, which revealed a friable tumor, easily differentiated from the normal parenchyma, with cystic components. The histopathological examination demonstrated pleomorphic xanthoastrocytoma with malignant transformation. Histologically, the tumor at first procedure was composed of pleomorphic astrocytes with multinucleated and foamy cells. A rare case of malignant transformation in pleomorphic xanthoastrocytoma is presented, discussed and illustrated in this paper.
\end{abstract}

KEY WORDS: xanthoastrocytoma, astrocytoma, tumor, histopathology.

\section{Transformação maligna de xantoastrocitoma pleomórfico: relato de caso}

\begin{abstract}
RESUMO - Um caso raro de transformação maligna de xantoastrocitoma pleomórfico é apresentado, discutido e ilustrado neste estudo. Descrevemos um caso de xantoastrocitoma pleomórfico diagnosticado como lesão isodensa no lobo fronto-temporal direito, em uma paciente de 26 anos. Na cirurgia, encontrou-se tumor mole, de cor amarelada, com cavidade cística. Cinco meses após o procedimento, a paciente foi submetida a nova intervenção que revelou um tumor friável, facilmente diferenciado do parênquima normal, com componentes císticos. O exame histopatológico demonstrou um xantoastrocitoma pleomórfico com transformação maligna. 0 tumor, no primeiro procedimento, era formado por astrócitos pleomórficos com células vacuolizadas e multinucleadas.
\end{abstract}

PALAVRAS-CHAVE: xantoastrocitoma, astrocitoma, tumor, histopatologia.

Pleomorphic xanthoastrocytoma (PXA) is an astrocytic neoplasm with a relatively favourable prognosis, typically encountered in children and young adult. It is superficially located in the cerebral hemispheres, presenting involvement of the meninges, and a pleomorphic histological appearance that includes lipidized, GFAP-expressing tumor cells surrounded by a reticulin network ${ }^{1,2}$. Since its description by Kepes et al in 19791, PXA has been considered to have a favorable outcome compared to other astrocyte-derived tumors. However, MacCaulay et al. ${ }^{3}$ have revealed a mortality rate of $20 \%$.
Well-documented cases of malignant transformation in pleomorphic xanthoastrocytoma are rare in the literature. We report one case.

\section{CASE}

This 26 year-old female was admitted to the hospital with a history of seizures for the last five months. A CT-scan detected a cystic isodense right fronto-temporal lesion enhanced by contrast injection. At surgery, we found a soft yellow tumor with cystic cavities. We had some difficulties to differentiate the tumor from the normal brain, so only partial removal could be achieved. The patient was discharged home on anti-convulsive drugs. Due to the histo-

\footnotetext{
Department of Neurosurgery (OITJ, MAH, MNP), Department of Pathology (JNS), Federal University of São Paulo SP, Brazil (UNIFESP): ${ }^{1}$ Adjunct Professor of Neurosurgical Department (UNIFESP); ${ }^{2}$ Associated Professor of Neurosurgical Department of Jundiai Medicine School, São Paulo SP, Brazil; ${ }^{3}$ Adjunct Professor of Neurosurgical Department UNIFESP; ${ }^{4}$ Adjunct Professor of Department of Pathology UNIFESP; ${ }^{5}$ Assistent Professor of Neurosurgical Department of State University of São Paulo, São Paulo SP, Brazil.
}

Received 9 January 2002, received in final form 1 August 2002. Accepted 21 August 2002.

Dr. Oswaldo Ignácio de Tella Jr - Rua São Paulo Antigo 145 Bloco F Apto 11 - 05864-010 São Paulo SP - Brasil. FAX: 551155731780.

E-mail: detella@uol.com.br 


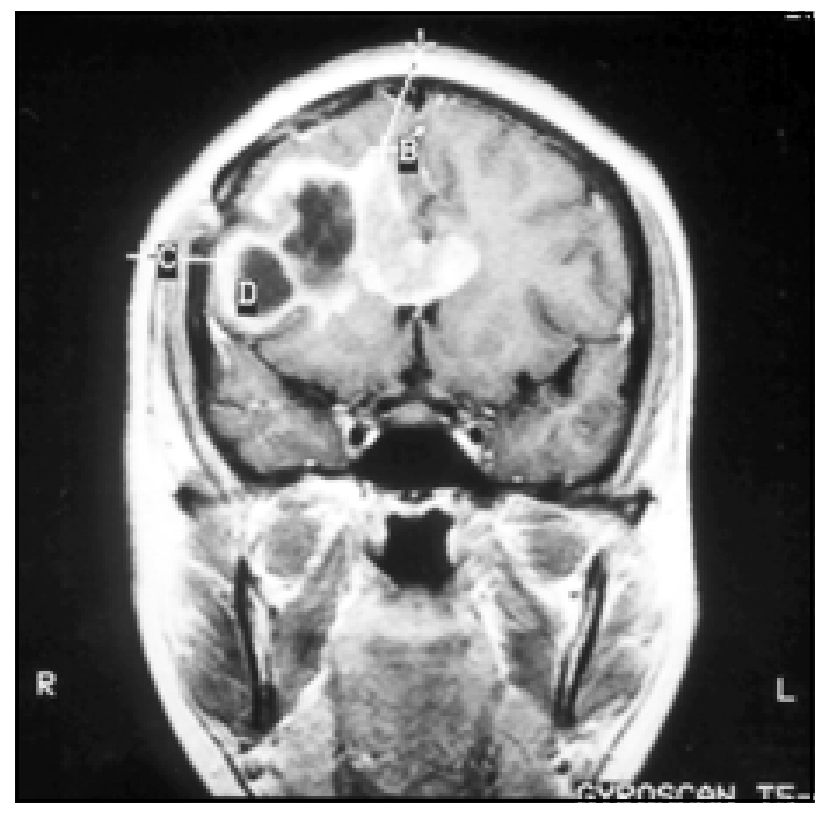

Fig 1. A huge isodense right fronto-temporal lesion, invading the corpus callosum with cystic cavities.

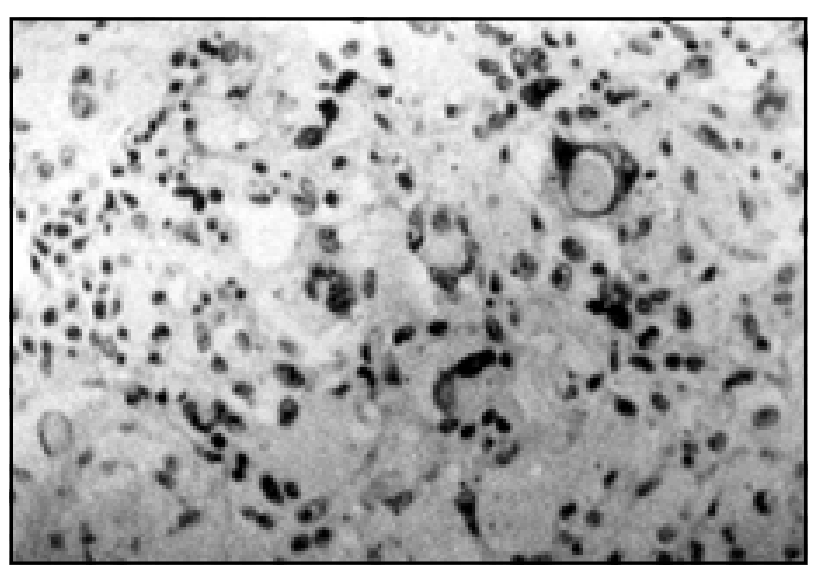

Fig 2. The tumor showing pleomorphic astrocytes with multinucleated cells and foamy cells. $H \& E, x 400$.

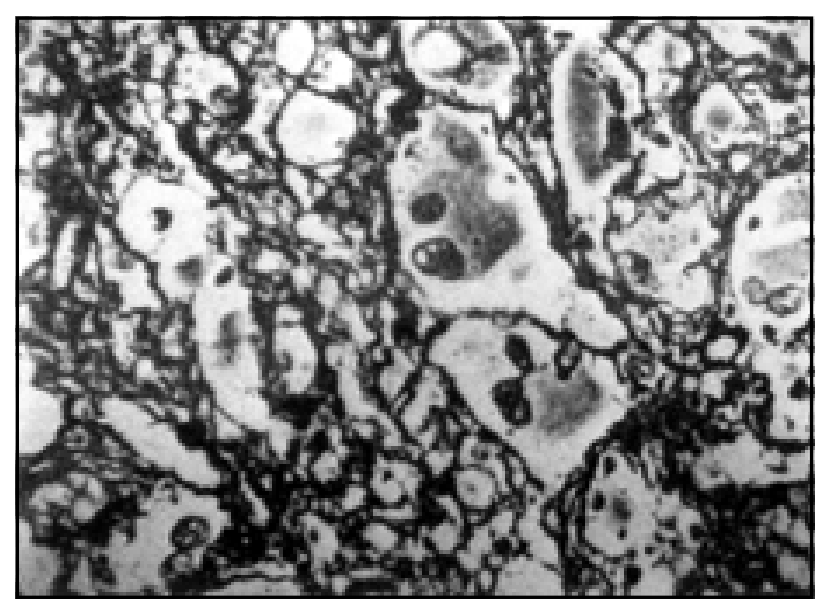

Fig 3. A dense reticulin network among pleomorphic astrocytes. Silver impregnation, $x 400$. pathologic diagnosis of a PXA without anaplasia, no further adjuvant radiotherapy or chemotherapy was performed.

Five months after surgery, the patient had a convulsive episode. On neurological examination a bilateral papiledema was found. MRI demonstrated a huge isodense right fronto-temporal lesion; which invaded the corpus callosum with cystic cavities on T1 weighted images, enhanced after gadolinium injection (Fig 1). Surgical exploration revealed a friable tumor easily differentiated from the normal parenchyma, with cystic components. The histopathological examination demonstrated a PXA with a malignant transformation.

Histopathological findings - Histologically, the tumor on the first procedure was composed of pleomorphic astrocytes (Fig 2) with multinucleated and foamy cells. A dense reticulin network and lymphocytic infiltrations were found (Fig 3). Necrosis and vascular proliferations were not observed. A second resection showed the same aspect but there were areas with small fibrillary astrocytes, mitoses, multilayered vascular cells and areas of necrosis. The reticulin network had disappeared (Fig 4,5). The diag-

Fig 4. Tumor showing areas with small fibrillary astrocytes and necrosis. $H \& E, x 400$.

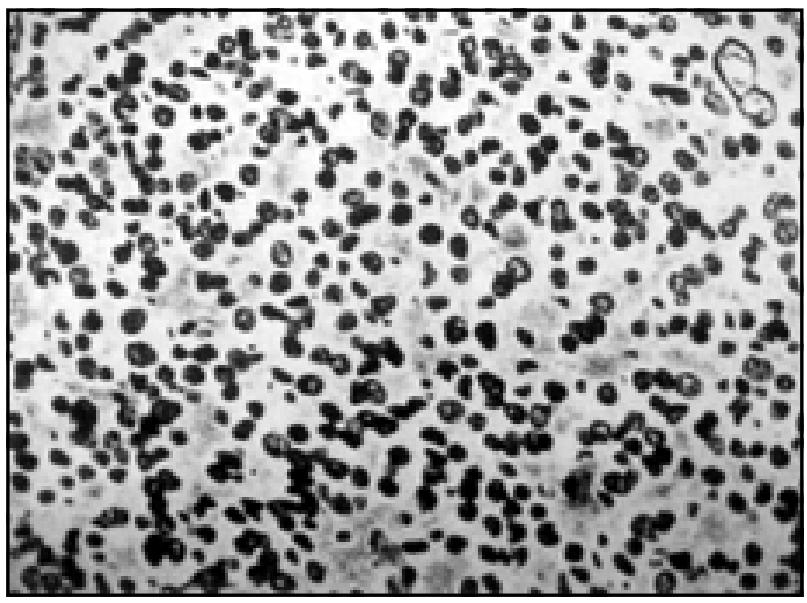

Fig 5. The reticulin network had disappeared among the small astrocytes. Silver impregnation, $x 400$. 
nosis was glioblastoma. The neoplastic cells were positive for glial fibrillary acidic protein. The MIB-1 labeling index (a marker of cell proliferation) in the initial tumor was $0.2 \%$ and the recurrent tumor had a MIB-1 labeling index of $5.8 \%$.

\section{DISCUSSION}

PXAs have been regarded as rather benign tumors despite the cellular pleomorphism. Clinical observations disclose common features of these neoplasms: patients are usually below 30 years of age; the tumors are located predominantly in the temporal and parietal regions; they have cystic appearance and they are frequently superficially located. Epileptic seizures are a typical initial symptom.

The initial clinical, radiological and histological features of this tumor were those of a PXA.

With some notable exceptions, pleomorphic xanthoastrocytomas behaves in a less malignant fashion than it might be suggested by their highly pleomorphic histology. However, in cases proven to be fatal, they usually have undergone transition to anaplastic astrocytoma or glioblastoma. Recurrences may show a histological pattern analogous to the original tumor, but increasing anaplasia may also be set $^{4-11}$. Pleomorphism may cease to be a feature and closely packed smaller cells may come to dominate the tumor. MacCaulay et al. ${ }^{7}$ assume that a focus of small mitotically active cells is a sign of imminent malignant transformation. In addition, with increasing malignancy, the formerly rich reticulin network may become fragmented or disappear completely. Necrosis usually occur in these more anaplastic recurrences. Our case is in accordance with these observations. The patient presented a typical PXA that recurred as glioblastoma five months later, comparable to the cases reported by Kepes et al.,3, WeldonLinne et al. ${ }^{11}$ and one case described by Tonn et al. ${ }^{10}$.

Giannini et al. ${ }^{12}$ made a study based on 71 cases with available information regarding clinical and the- rapeutic data and follow-up collected form the literature, confirming that PXA has a 70\% 10-years survival time, and mitotic index and extension of resection appear to be the main predictor factors of recurrence and survival rate.

The rarity of PXA demands neuropathologic experience to find the correct diagnosis, since misinterpretation as glioblastoma might cause harmful therapeutically decisions. The clinical course of patients is not always favorable. A close follow-up is needed in order to detect any recurrence with malignant transformation.

Acknowledgment - We are grateful to Karina Gazzonato Pereira for her expert assistence in the review of the manuscript.

\section{REFERENCES}

1. Kepes JJ, Rubinstein LJ, Eng LF. Pleomorphic xanthoastrocytoma: a distinctive meningocerebral glioma of young subjects with relatively favorable prognosis: a study of 12 cases. Cancer 1979;44:1839-1852.

2. Kepes JJ. Pleomorphic xanthoastrocytoma: the birth of a diagnosis and a concept. Brain Pathol 1993;3:269-274.

3. MacCaulay RJ, Jay V, Hoffman HJ, Becker LE. Increased mitotic activity as a negative prognostic indicator in pleomorphic xanthoastrocytoma: case report. J Neurosurg 1993;79:761-768.

4. Allegranza A, Ferraresi S, Bruzzone M, Giombini S. Cerebro-meningeal pleomorphic xanthoastrocytoma: report on four cases. Clinical, radiologic and pathological features (including a case with malignant evolution). Neurosurgery 1991;14:43-49.

5. Daita G, Yonemasu Y, Muraoka S, et al. A case of anaplastic astrocytoma transformed from pleomorphic xanthoastrocytoma. Brain Tumor Pathol 1991;8:63-66

6. Kepes JJ, Rubinstein LJ, Ansbacher L, Schreiber DJ. Histopathological features of recurrent pleomorphic xanthoastrocytomas: further corroboration of the glial nature of this neoplasm: a study of three cases. Acta Neuropathol 1989;78:585-593.

7. MacCaulay RJ, Becker LE, Jay V. Transformation of pleomorphic xanthoastrocytoma to glioblastoma: a case documented with immunogold electron microscopy. J Neuropathol Exper Neurol 1992;51:365.

8. Leonard N, Alcutt DA, Farrell MA. Fatal pleomorphic xanthoastrocytoma with meningeal gliomatosis. Histopathology 1998;32:375-378.

9. Prayson RA, Morris HH $3^{\text {rd }}$. Anaplastic pleomorphic xanthoastrocytoma. Arch Pathol Lab Med 1998;122:1082-1086.

10. Tonn JC, Paulus W, Warmuth-Metz M, Schachenmayr W, Sorensen N, Roosen K.Pleomorphic xanthoastrocytoma: report of six cases with special consideration of diagnostic and therapeutic pitfalls. Surg Neurol 1997;47:162-169.

11. Weldon-Linne CM, Victor TA, Groothuis DR, Vick NA. Pleomorphic xanthoastrocytoma: ultrastructural and immunohistochemical study of a case with a rapidly fatal outcome following surgery. Cancer 1983;52:2055-2063.

12. Giannini C, Scheithauer BW, Burger PC, et al. Pleomorphic xanthoastrocytoma: what do we really know about it? Cancer 1999;85:2033-2045. 